Asian J Agric \& Biol. 2021(3).

\title{
Allelopathic effect of prickly chaff flower (Achyranthes aspera L.) used as a tool for managing noxious weeds
}

\author{
Muhammad Ehsan Safdar, Adeela Aslam, Rafi Qamar*, Amjed Ali, Muhammad Mansoor Javaid, Muhammad \\ Sikander Hayyat, Ali Raza \\ Department of Agronomy, College of Agriculture, University of Sargodha, Sargodha, Pakistan
}

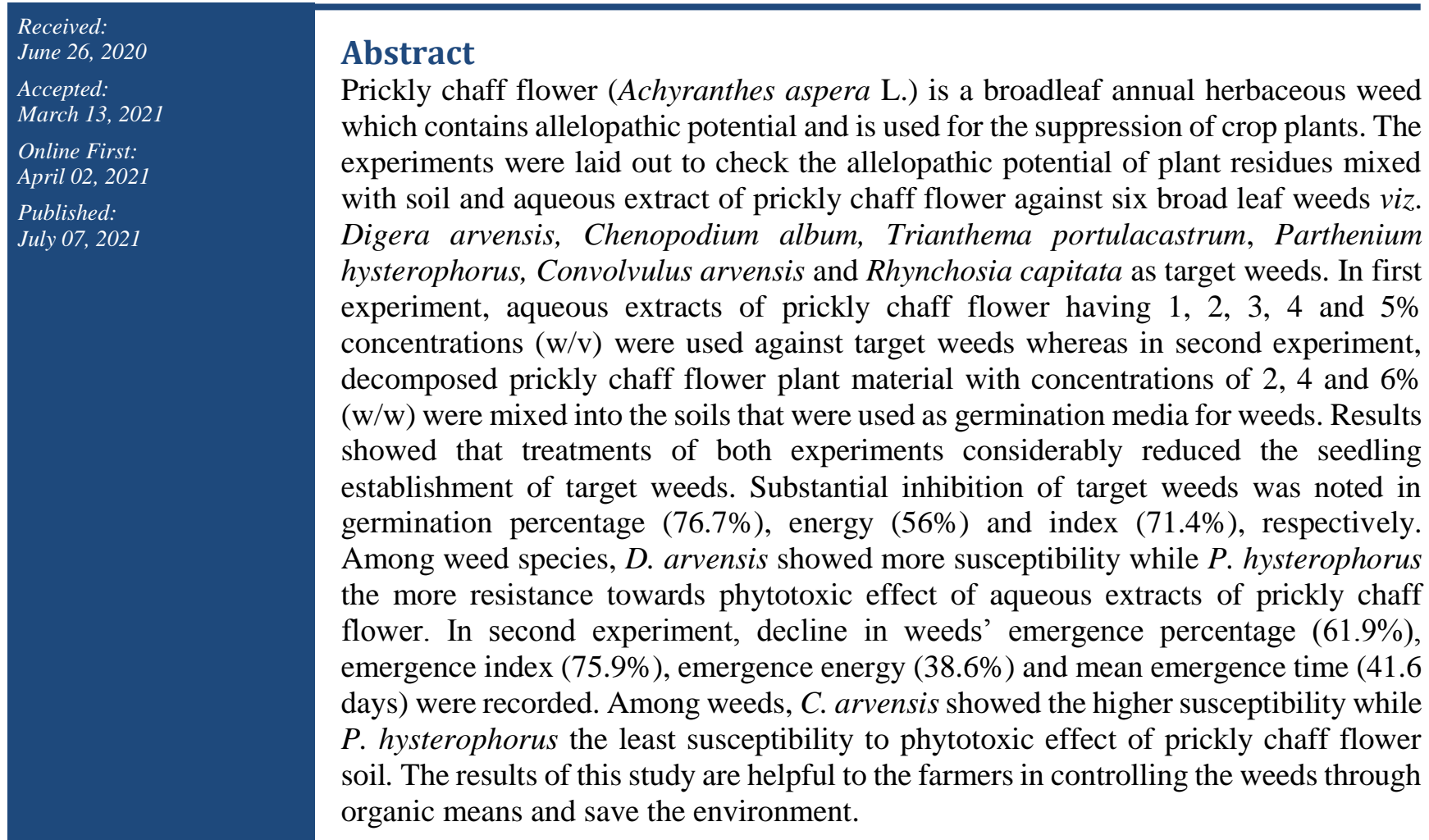

Keywords: Allelopathy, Broad leave weeds, Plant extracts, Inhibition, Weed management

\section{How to cite this:}

Safdar ME, Aslam A, Qamar R, Ali A, Javaid MM, Hayyat MS and Raza A, 2021. Allelopathic effect of prickly chaff flower (Achyranthes aspera L.) used as a tool for managing noxious weeds. Asian J. Agric. Biol. 2021(3): 202006370. DOI: https://doi.org/10.35495/ajab.2020.06.370

This is an Open Access article distributed under the terms of the Creative Commons Attribution 3.0 License. (https://creativecommons.org/licenses/by/3.0), which permits unrestricted use, distribution, and reproduction in any medium, provided the original work is properly cited.

\section{Introduction}

Weed is a plant that has been sprung up in its native natural world, gone through evolution process and continuously hindering the crop production and human activities (Aldrich and Kremer, 1997). Weeds 
compete with crop plants for nutrients space and light. Due to weed crop competition, agricultural and forest productions are decreased (Khan et al., 2004). However, there is bifurcation of weeds into two categories i.e. agrestals that interfere with crop ecosystems and ruderals that grow in waste lands and along the roadsides. The first category of weeds is harmful in agricultural land as these compete with crops, harbor insect-pest and diseases, reduce the quality of crop and animal products, increase the cost of production, hinder agricultural operations, play havoc with human health and reduce land value. The harmful effects of weeds supersede their optimistic values. Allelopathy is a biological process of releasing plant-produced chemicals into the environment through leachates of foliage, root exudates, volatilized compounds and decomposed plant products (Weston and Duke, 2003). Various weeds can release different allelopathic or phytotoxic chemicals known as allelochemicals which could reduce the germination and growth of neighboring plants. The phytotoxic ability of different weeds could be used for the management of other weeds. Chemical weed control is quick, effective and cheap method of weed management. However, non-judicious herbicide use causes various ecological and health related issues. Indiscriminate use of herbicides results in environmental pollution (Fernandez-Perez, 2007), food toxicity (Koesukwiwat et al., 2010), despaired biological diversity (Ros et al., 2006), alteration in weed community structure (Schooler et al., 2010) and development of herbicide resistant weeds (Marshall et al., 2010). Allelopathy could be used as best alternative to chemical weed control (Macias et al., 2007). Plant species with higher allelopathic potential can be employed in weed management by growing them as intercrops, using in crop rotation, or application of their mulches (Farooq et al., 2020). Moreover, their aqueous extracts can be use in tank mixture with herbicides in order to reduce herbicide doses (Afridi and Khan, 2014).

Prickly chaff flower (Achyranthes aspera L.) is an herbaceous member of family Amaranthaceae that has perennial growth habit. It completes its life cycle within a year and has ability to survive more than one year. It is propagated both sexually and asexually and is woody in nature. This weed is most commonly present in Pakistan at waste lands and roadsides (Shafique et al., 2007). Mostly, it has an ability to grow on moist places, both under the sunshine and shady places (Vora et al., 1989). It survives as invasive weed in various zones of pacific islands i.e. Mariana Island, Hawaii, Fiji, Samoa, French Polynesia, Cook Islands and French Polynesia (Daehler et al., 2004). Because of its spiny nature, it sticks easily with animal's hair, human cloth or bird's feather thus easily spreads from one place to another (Bansal and Sen, 1981). It has become very aggressive and fast growing and can survive in variable environmental conditions (Ahmad et al., 2012). It also known as predominant weed of sugarcane and corn (Qureshi et al., 2002). Prickly chaff flower is highly phytotoxic plant. The presence of various allelopathic compounds including alkaloids, dihydroxy ketones, saponins, oleonolic acid and phenolics (chromatotropic, gallic, caffeic, 4hydroxy-3-methoxy benzoic, m-coumaric and syringic acids) has been detected in this plant (Srivastav et al., 2011; Safdar et al., 2016). It has been documented that whole plant of prickly chaff flower has higher phenolic contents $\left(5779 \mathrm{mg} \mathrm{L}^{-1}\right)$ and has ability to restrict the growth of parthenium weed (Safdar et al., 2016). Allelopathic capability of prickly chaff flower against the growth and yield of crops has been examined in previous studies. Root extract of prickly chaff flower was demonstrated to be successfully in inhibiting the emergence of Pennisetum americanum, Cyamopsis tetragonoloba and Zea mays (Tanveer et al., 2014). Additionally, its phytotoxic effect on cotton, cow pea, wheat and black gram has been demonstrated (Kruse et al., 2000). The main objective of the current study is to determine the phytotoxic capability of prickly chaff flower against six noxious weeds viz. parthenium, field bindweed, goosefoot, jumby-bean, horse purslane and false amaranth. The hypothesis was whether the allelopathic behavior of this weed could be utilized for ecofriendly and sustainable management of the abovementioned problematic weeds.

\section{Material and Methods}

Study was undertaken for two years 2014 and 2015 in the Laboratory of Department of Agronomy, College of Agriculture, University of Sargodha, Sargodha, Pakistan. Study site lies at $32^{\circ} 5.01^{\prime} \mathrm{N}$ latitude, $72^{\circ} 40.26^{\prime} \mathrm{E}$ longitude and 252 (meters) altitude.

\section{Determination of phytotoxins in aqueous extract of prickly chaff flower}

For the detection and evaluation of speculated allelochemicals, aqueous extract of prickly chaff flower was synthetically analysed by using a 
Shimadzu HPLC (Table-1) framework furnished with an UV detector (Model SCL-10A, Tokyo, Japan). Standards of suspected allelochemicals (Aldrich, St Louis, USA) were run also for their detection and measurement. Concentration (Conc.) of each isolated compound was determined by the following equation:

Concentration $(\mathrm{ppm})=\frac{\text { Area of the sample }}{\text { Area of the standard }} \times$ Concentration of the standard $\times$ Dilution factor

Table-1. Determination of phytotoxins in water extract of Prickly chaff flower Phenolics

\begin{tabular}{|l|c|}
\hline \multicolumn{1}{|c|}{ Phenolics } & Concentration $\left(\mathbf{m g ~ L}^{\mathbf{1}} \mathbf{)}\right.$ \\
\hline Gallic acid & 16.85 \\
\hline Caffeic acid & 7.41 \\
\hline $\begin{array}{l}\text { 4-hydroxy-3-methoxy benzoic } \\
\text { acid }\end{array}$ & 24.77 \\
\hline m-coumaric acid & 3.13 \\
\hline Chromatotropic acid & 63.83 \\
\hline Syringic acid & 9.21 \\
\hline
\end{tabular}

\section{Aqueous extract bioassay studies}

Prickly chaff flower plants were collected from citrus garden in Tehsil Sillanwali ( $31^{\circ} 49^{\prime}$ North, $72^{\circ} 32^{\prime}$ East), district Sargodha, Pakistan in November, 2014 and 2015. The collected plants were thoroughly washed with distilled water to remove dust. The collected plants were carried to laboratory of the Department where plants were cut into small pieces using cutter. To dry the samples, those were spread in shade and then placed into electric oven (WFO600ND, Tokyo Rikakiai Co. Ltd., Japan) at $70^{\circ} \mathrm{C}$ for the period of 48 hours. After drying, 1-gram sample was immersed into 20 liters distilled water for one day (Hussain and Gadoon, 1981). Electrical shaker was used to make homogenous mixture of sample for two hours. Then mixture was filtered through slim muslin fabric to isolate the watery concentrate and plant trashes. In this way, collected filtrate was considered to be of $5 \%$ concentration $(\mathrm{w} / \mathrm{v})$. The $5 \%$ water extract was converted into $1,2,3$, and $4 \%(\mathrm{w} / \mathrm{v})$ concentrations with double distilled water. These extracts of $1-5 \%$ concentrations were well-kept-up separately in pre-cleaned glass bottles and were labeled for further study.

Twenty seeds of each weed i.e. parthenium, field bind weed, goosefoot, jumby-bean, horse purslane and false amaranth were placed in petri plates having filter paper, and extract $(3 \mathrm{ml})$ was applied to each petri plate. In control, distilled water $(3 \mathrm{ml})$ was applied instead of plant extract. Para film material was wrapped around the petri plates to avoid the evaporation. Treatments were arranged in CRD with factorial arrangement having four replications. Then petri plates were placed in germinator for a period of 15 days. For summer season weeds (parthenium, field bindweed, jumby-bean, horse purslane and false amaranth), temperature was kept $30^{\circ} \mathrm{C}$ while for winter weed (goosefoot), temperature was kept $25^{\circ} \mathrm{C}$. Seeds that germinated were counted from each petri plate on daily basis for the period of 15 days.

\section{Soil incorporated plant residues bioassay studies} Prickly chaff flower plants were uprooted from agronomic field area, College of Agriculture, Sargodha, Pakistan. Collected plants were chopped by cutter and then dried under the shady place, and then kept into electric oven at $70^{\circ} \mathrm{C}$ for 48 hours. Soil to be used for weed seed sowing was collected from vegetation free site. The treatments were composed of 2, 4 and $6 \%(\mathrm{w} / \mathrm{w})$ soil-decomposed plant residues. For this purpose, plastic pots $\left(46 \times 17 \mathrm{~cm}^{2}\right)$ were filled with $100 \mathrm{~g}$ of soil and mixed with 2, 4 and $6 \mathrm{~g}$ of plant residues of prickly chaff flower then kept into Laboratory for whole month to complete the decay process. Soil was kept moist with distilled water when required during the entire decomposition time. After decomposition, those soils were used as germinating media for the sowing of all the six weed species (parthenium, field bind weed, goosefoot, jumby-bean, horse purslane and false amaranth). Twenty seeds of each weed were sown in each pot. For the period of 15 days, pots were retained in Germinator (Robus Technologies). Treatments were arranged in CRD with factorial arrangement having four replications. For summer season weeds (parthenium, field bindweed, jumby-bean, horse purslane and false amaranth), the temperature was kept $30^{\circ} \mathrm{C}$ while for winter weed (goosefoot), temperature was kept $25^{\circ} \mathrm{C}$. Seeds that emerged were counted from each petri plate on daily basis for the period of 15 days.

\section{Observations recording}

Seed germination/emergence percentage, emergence index, mean germination time, time to $50 \%$ germination, emergence energy was calculated on daily basis.

\section{Germination / emergence percentage (GP / EP)}

Germination / emergence was calculated by using following formula as suggested by AOSA (1990): 


$$
G P / E P=\frac{\text { Germinated } / \text { emerged seeds }}{\text { Total seeds }} \times 100
$$

\section{Germination / emergence index (GI / EI)}

Germination / emergence index was deliberated by using the following formula by AOSA (1990):

$$
\begin{aligned}
G I / E I=\frac{\text { No. of germinated/emerged seeds }}{\text { Days of first count }} \\
+\frac{\text { No. of germinated /emerged seeds }}{\text { Days of final count }}
\end{aligned}
$$

\section{Mean germination / emergence time (MGT)}

Mean germination / emergence time was determined by using formula of Ellis and Roberts (1981)

$M G T / M E T=\frac{\Sigma \mathrm{Dn}}{\Sigma \mathrm{Dn}}$

Where " $n$ " showed number of germinated / emerged seeds on day "D" and "D" showed days of count.

\section{Germination / emergence energy (GE / EE)}

Germination / emergence energy was obtained by using following formula of Ruan et al. (2002)

\footnotetext{
$G E / E E=$

No.of germinated/emerged seed till 4th day of sowing $\times 100$

Total no.of germinated/emerged seeds till last count
}

\section{Statistical analysis}

Statistical Fisher's analysis techniques were applied on all variables, and DMR test at 5\% probability (Steel et al., 1997) was used for treatment comparison by applying the statistical program SAS 9.1 (SAS Institute, 2008). Graphs were created using SigmaPlot software (Systat Software, 2008).

\section{Results and Discussion}

\section{Aqueous extract bioassay studies \\ Germination \%}

Germination rate showed general performance of seeds in response to toxic action of several compounds. Information in regard to germination percentage of weeds as impacted by prickly chaff flower extracts was exhibited in Figure 1. It is clear from the information that extract of prickly chaff flower with all concentrations statistically influenced the germination of all weeds. Germination percentage of weeds was consistently diminished up to 10.8 $72.3 \%$ by the increase in water extract concentration from 1 to $5 \%$. In this way the lowest germination $(31.4 \%)$ was noted with water extract having the highest $(5 \%)$ concentration. Among weeds, most prominent phytotoxic effect of prickly chaff flower concentrate was seen on $D$. arvensis giving least germination $(35.8 \%)$. Germination of $D$. arvensis could not occur when extract of prickly chaff flower having concentration of 5\% was applied. The least phyto-inhibitory influence was observed on $P$. hysterophorus. Regarding weed $\times$ concentrations interaction, $D$. arvensis presented the least germination \% (6.3 and 0) in response to water extract of prickly chaff flower with 4 and 5\% concentration, respectively. The phytotoxic potential of prickly chaff flower extracts against germination of weeds was probably due to presence of phenolics in higher concentrations as determined by Srivastav et al. (2011) and Safdar et al. (2016). Allelochemicals especially phenolics influence the physiological processes of seed as these are present in soluble form in plant extracts (Leather and Einhelling. 1988).

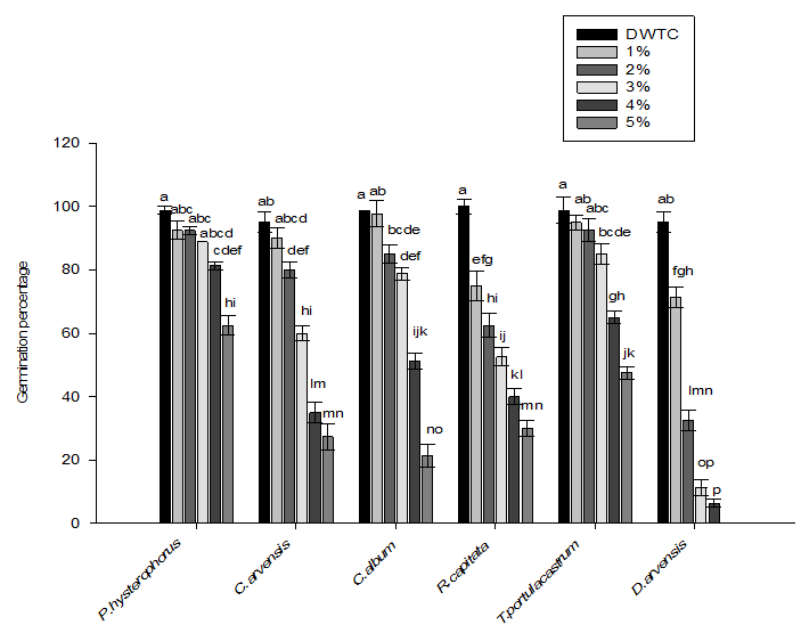

Figure-1. Effect of soil incorporated aqueous extracts of prickly chaff flower on germination percentage of weeds species.

The minimum phytotoxic effect of prickly chaff flower extract was noted on parthenium weed as it sowed the highest germination $(86.04 \%)$. However, significant reduction in germination percentage of parthenium weed started to occur by increasing the concentration of prickly chaff flower extract beyond $4 \%$. This was due to reason that as concentration of prickly chaff flower was increased, the concentration of allelochemicals also increased. Results of Randhawa et al. (2002) strengthen the findings of our results that germination $\%$ of horse purslane was 
inhibited by liquid extract of Sorghum bicolor due to existence of allelochemicals in it. Moreover, by increasing the concentration of those extracts, the germination inhibition was also enhanced. Islam et al. (2014) also supported our results by documenting the reduction in germination percentages of mung bean, wheat, gram and maize by the application of Chenopodium murale L. extract. By the increase in concentration of that extract, the germinations of test crop were gradually decreased.

\section{Germination index (GI)}

Germination index (GI) of six weeds as influenced by water extract of prickly chaff flower at various concentrations has been shown in Figure 2. It clearly expresses that the water extract of prickly chaff flower significantly influenced the germination index of target weeds. Peak inhibition in germination index as caused by the prickly chaff flower extracts was recorded on $D$. arvensis and field bindweed and as these expressed least GIs of 6.97 and 6.55, correspondingly.

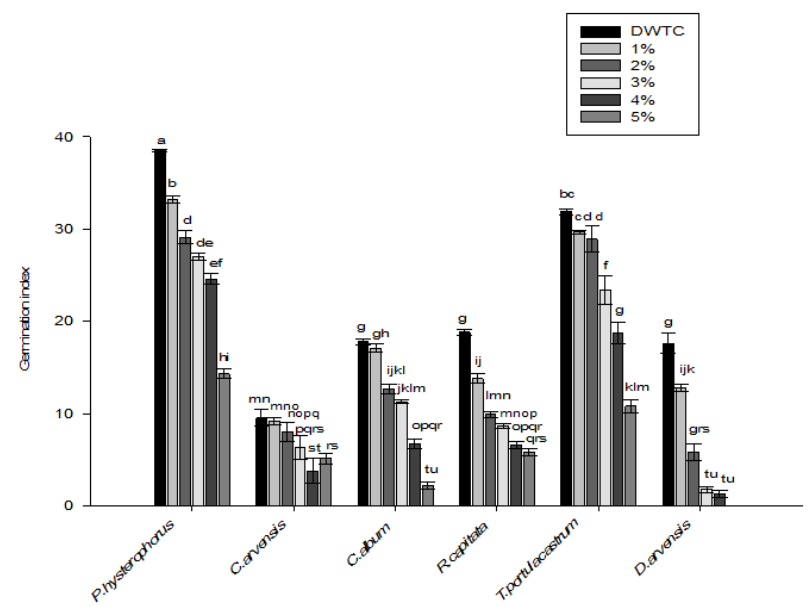

Figure-2. Effect of soil incorporated aqueous extracts of prickly chaff flower on germination index of weeds species.

Conversely, the most minimal phytotoxic impact of prickly chaff flower water extract was noted on $P$. hysterophorus as this weed demonstrated higher GI (27.78). Interaction between weed $\times$ concentrations, D. arvensis presented the least GI (1.3 and 0$)$ in response to water extract of prickly chaff flower with 4 and 5\% concentration, respectively. Whereas the most elevated GI (33.2) was noted with $P$. hysterophorus with the use of $1 \%$ water extract of prickly chaff flower. The reduction in GI of weed species by the use of prickly chaff flower extract was due to the retardation in germination speed on account of presence of phenolics in higher concentration (5779 $\mathrm{mg} \mathrm{L}^{-1}$ ) as reported by Safdar et al. (2016). Similarly, Wakjira et al. (2009) documented that germination index of lettuce was negatively influenced by the application of plant parts extract of parthenium. In the same way, Islam et al. (2014) also demonstrated a negative influence of $C$. murale extracts with different concentrations on GI of mung bean and wheat.

\section{Mean germination time (MGT)}

Mean germination time is an important indicator of germination performance of seeds in terms of germination speed. Higher the value of mean germination time, slower will be the germination of seed. Analysis of variance of this parameter regarding concentrations, weeds and concentration $\times$ weed interactions is shown in Figure-3. It is obvious from the data that aqueous extracts of A. aspera with various concentrations delayed the germination of six weed species in a differential pattern. Maximum delay in germination completion was noted with 5\% concentrated extracts of all weed species except $C$. arvensis and $D$. arvensis as aqueous extracts of $A$. aspera remained unable to cause significant delay in germination of these weed species. Among weed species, C. album was affected maximally by $A$. aspera aqueous extract as its seeds took maximum mean germination time (8.30 days) while $R$. capitata seeds were least affected by $A$. aspera aqueous extract as they took minimum mean germination time (3.57 days). Regarding concentration $\times$ weed interaction, significantly the highest mean germination time was recorded with $C$. album in response to aqueous extracts of $A$. aspera with 3, 4 and 5\% concentrations. The prolongation in mean germination time of weeds in response to the application of various concentrations of aqueous extracts of $A$. aspera was probably due to their deleterious effects against metabolic activities of weed seeds that slowed down the germination process. Our findings are supported by the results of Tanveer et al. (2014) who reported a significant decrease in germination index of four cops viz. pearl millet, guar, sorghum and maize in response to aqueous extracts of various plant parts of $A$. aspera. Our results are also in line with the findings of Huy (2004) who observed a significant delay in mean germination time of chir-pine seedlings due to strong allelopathic effect of parthenium. 


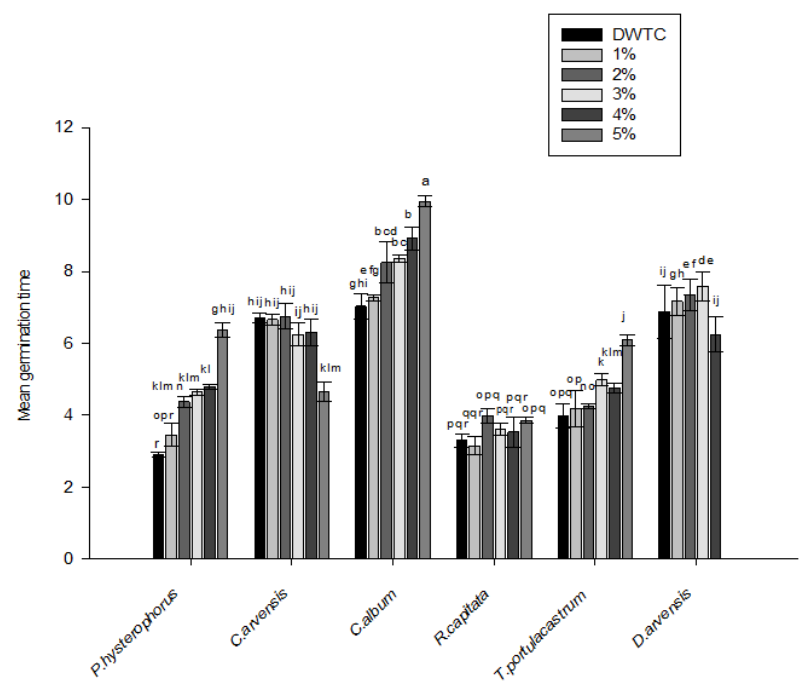

Figure-3. Effect of soil incorporated aqueous extracts of prickly chaff flower on mean germination time of weeds species.

\section{Germination energy (GE)}

Germination energy (GE) is determined by counting the germinated seeds on 4th day of germination. More the GE, more would be the germination completion speed of seeds. Information exhibited in Figure 4 showed that water extracts of prickly chaff flower with concentrations of 2 to $5 \%$ drastically diminished the GE of all weed species except $P$. hysterophorus and $T$. portulacastrum. With respect to comparison among weeds, $C$. arvensis and $D$. arvensis were extraordinarily influenced by the allelopathicity of prickly chaff flower by indicating minimum GE ( (41 and 43\%), correspondingly. Conversely, $P$. Hysterophorus and T. portulacastrum were minimally influenced as these indicated GE of $56 \%$ and $54 \%$, respectively. Regarding concentration $\times$ weed interaction, significantly the lowest GE (9\% and $0 \%$ ) were recorded with $C$. arvensis and $D$. arvensis in response to aqueous extract of $A$. aspera with $5 \%$ concentrations. The inhibition of germination energy of weeds in presence of prickly chaff flower extracts might be due to existence of phyto-restrictive chemicals in those as mentioned by Safdar et al. (2016). These allelochemicals interrupted the biochemical processes of seed germination. Our revelations are supported by the observations of $\mathrm{Mu}$ et al. (2008) who revealed a statistically lower the GE of various cultivars of wheat because of water concentrates of various weeds due to their phytotoxic influence.

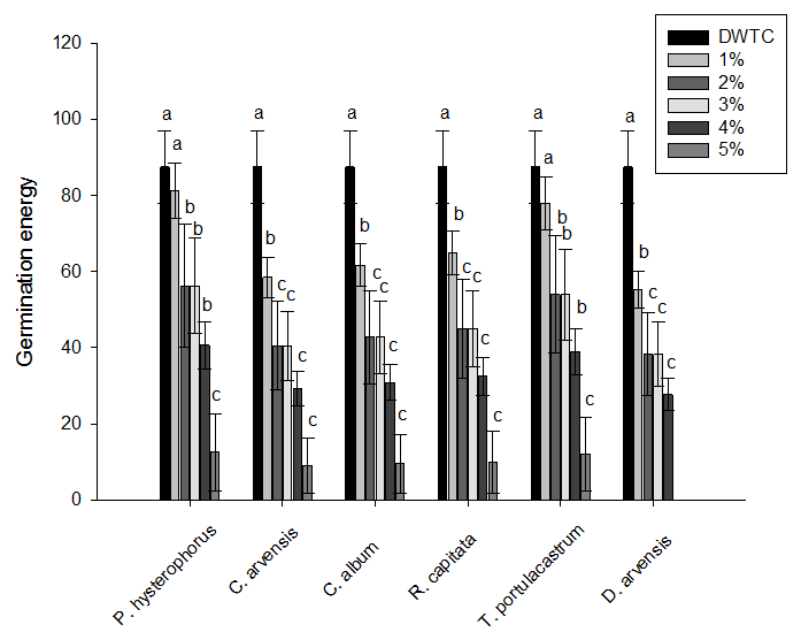

Figure-4. Effect of soil incorporated aqueous extracts of Prickly chaff flower on germination energy of weeds species.

\section{Incorporated plant residues soil bioassay studies Emergence percentage (\%)}

It is obvious from Figure 5, that decomposed residues of prickly chaff flower with various concentrations had significantly the toxic impact on the emergence percentage of all target weeds. By the increase in soil residue concentration, germination percentage of weeds was gradually decreased. The minimal emergence (37.4\%) of weeds was found in response to soil-decomposed plant residue of prickly chaff flower having $6 \%$ concentration. Most extreme inhibitory impact of prickly chaff flower plant residue was seen on $C$. album, D. arvensis, and $C$. arvensis as they showed the least emergence of 60.0, 56.8 and $56.4 \%$. Conversely, the least inhibitory impact of decomposed material of prickly chaff flower was seen on $P$. hysterophorus, this weed demonstrated the most elevated emergence (92.81\%). However, $R$. capitata and $T$. portulacastrum were found to be moderately susceptible. Regarding concentration $\times$ weed interaction means, all weed species showed the lowest emergence percentage at soil residue with $6 \%$ concentration. Moreover $C$. arvensis weed germinated in soil residue of $6 \%$ concentration showed the lowest emergence percentage (18\%). The suppressive action of soil-decomposed plant residues of prickly chaff flower against emergence of weeds might be due to existence of phenolic chemicals in it. Similar findings were recorded by Dogra and Sood (2012) who stated that $P$. hysterophorus decomposed plant material in soil suppressed germination percentage of three weed species Cassia tora, Achyranthes aspera and Acacia 
catechu Wild. Soil decomposed remains of parthenium reduced the germination percentage of various plant species (Dogra and Sood, 2012). Safdar et al. (2014) recorded the similar type of phytoinhibitory effect of parthenium soil against germination of maize and found different phenolic chemicals in water extract of that soil.

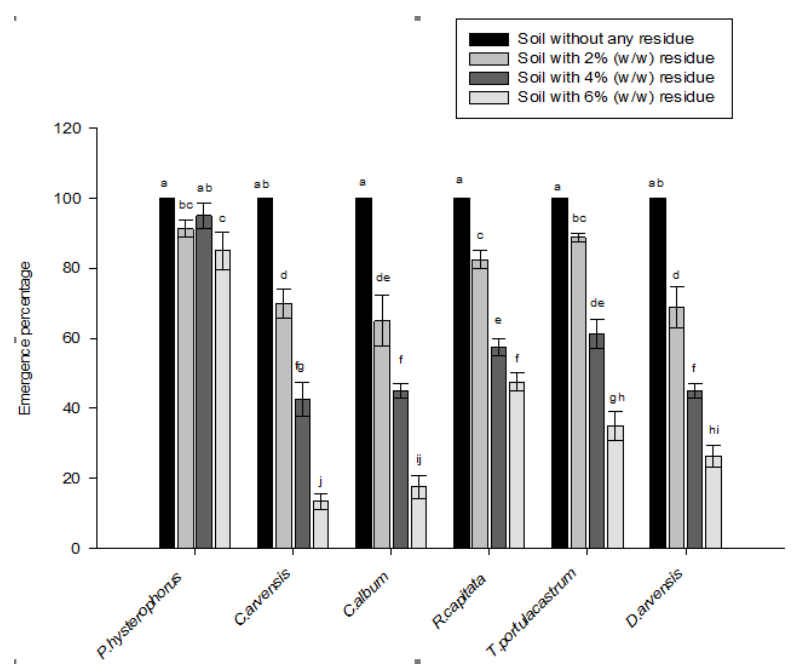

Figure-5. Soil incorporated residues concentrations of prickly chaff flower on emergence percentage of weeds species.

\section{Emergence index (EI)}

Emergence index measures the relative efficiency of emergence of seeds with respect to time taken by them. Study of individual comparison of means for emergence index (Figure-6) revealed that soil incorporated plant residues of A. aspera at their all concentrations significantly reduced the emergence index of weed species tested. The suppressive effect was successively enhanced by increasing concentration of $A$. aspera plant residues in soil. Maximum suppressive effect was shown by $A$. aspera soil incorporated residue of $6 \%$ concentration as it gave the lowest emergence index (3.47). Among weeds, the maximum inhibitory effect by $A$. aspera soil incorporated plant residues was observed on $C$. arvensis as it gave minimum emergence index of 3.67. Minimum inhibition of emergence index was observed on $T$. portulacastrum and $P$. hysterophorus as they gave maximum emergence indices 12.80 and 13.66, respectively. Regarding concentration $\times$ weed interaction means, all weed species except $P$. hysterophorus showed the lowest emergence index at the highest $(6 \%)$ concentration whereas $C$. arvensis both at 4 and $6 \%$ concentrations. It can be presumed that $6 \%$ was the inhibitoriest concentration of $A$. aspera compost for broadleaf weeds.

The highest suppressive effect of $6 \%$ concentrated soil incorporated $A$. aspera plant residue against test weed species might be attributed to its highest phytotoxic action against them. Our results are supported by findings of Khaliq et al. (2011) who reported suppression in emergence index of $T$. portulacastrum in response to soil incorporated plant residues of sorghum, sunflower and brassica by posing allelopathic effects. Our results also have affirmative relationship with the findings of Rajiv et al. (2013) who reported that parthenium compost with dung in different ratios gave significant reduction in growth and emergence index related parameters of different plant species.

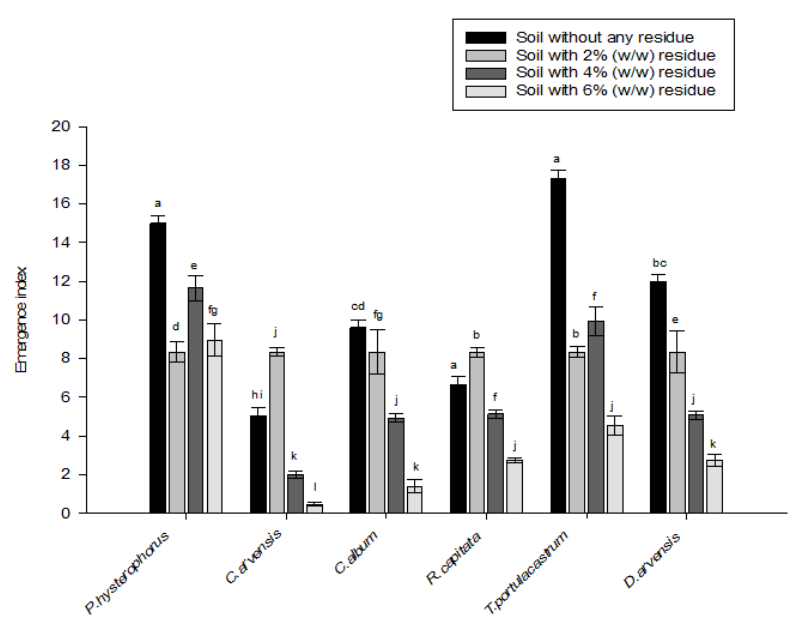

Figure-6. Soil incorporated residues concentrations of prickly chaff flower on emergence index of weeds species.

\section{Mean emergence time (MET)}

Figure-7 contains the individual comparison of means of mean emergence time of different weed species at different compost concentrations. It can be observed that significant gradual prolongation in mean emergence time of weed species occurred by increasing the concentration of $A$. aspera soil incorporated plant residues. Consequently, among concentrations, the longest mean emergence time (10.20 days) was noted at $6 \%$ concentration. Among concentrations, the longest mean emergence time (10.20 days) was noted at 6\% concentration. Among weeds, $C$. arvensis and $C$. album took the maximum mean emergence time (9.27 and 9.04 days). In contrast, $R$. capitata and $T$. portulacastrum were least affected by the phytotoxicity of $A$. aspera residue as 
the shortest mean germination time of 7.86 and 7.61 days was noted with these weed species respectively. The concentration and weed interaction means showed that $C$. album and $C$. arvensis took maximum time of 11.62 and 11.18 days, respectively.

The delay in germination accomplishment as a result of presence of $A$. aspera decomposed plant material in soil was probably due to the slowness in underlying metabolic processes of seed germination on account of presence of phytotoxic compounds in soil. Our findings match with the conclusions of Khaliq et al. (2011) who reported an increase in the mean emergence time of $T$. portulacastrum in response to the soil incorporated crop residues. Our results are also in line with the findings of Tanveer et al. (2010) who noted significant elongation in mean emergence time of crops such as wheat, chickpea and lentil by Euphorbia helioscopia L. extracts.

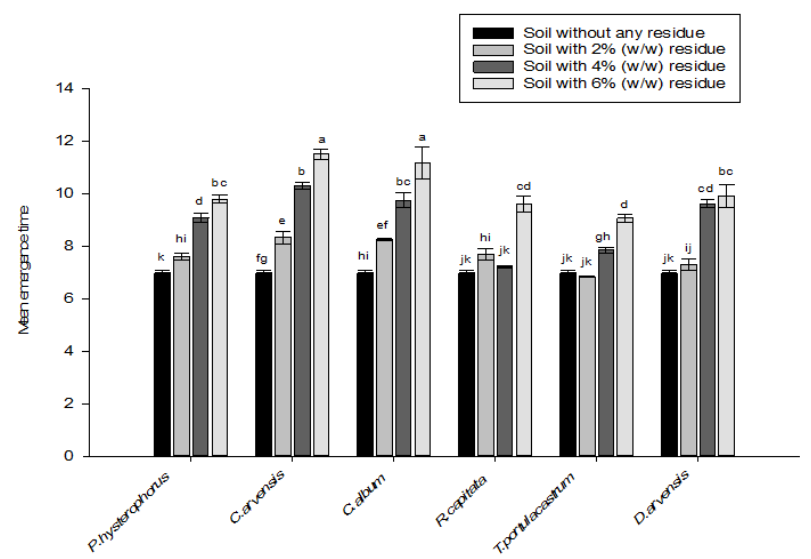

Figure-7. Soil incorporated residues concentrations of prickly chaff flower on mean emergence time of weeds species.

\section{Emergence energy (EE)}

Figure-8 presented the individual comparison of means of different compost concentrations and broadleaf weed species for emergence energy. It was observed that soil incorporated plant residues at their higher concentrations (4 and 6\%) could only be able to cause significantly reduction in emergence energy of weed species. The maximum effect was shown by soil incorporated plant residue of $6 \%$ concentration as it gave the minimum emergence energy (49.23). Among six broadleaf weed species, four weeds viz., $D$. arvensis, $R$. capitata, $P$. hysterophorus and $T$. portulacastrum were affected maximally. These weeds showed emergence energies of 56.36, 55.66, 54.01 and 55.31, respectively.
Regarding concentration $\times$ weed interaction means, weed species $P$. hysterophorus and $R$. capitata showed the lowest emergence energy in soil with $6 \%$ residue concentration whereas $C$. arvensis and $C$. album showed higher emergence energy at $2 \%$ concentrations. Safdar et al. (2014) also observed up to $40 \%$ reduction in emergence energy of maize sown in rhizospheric soil of parthenium weed.

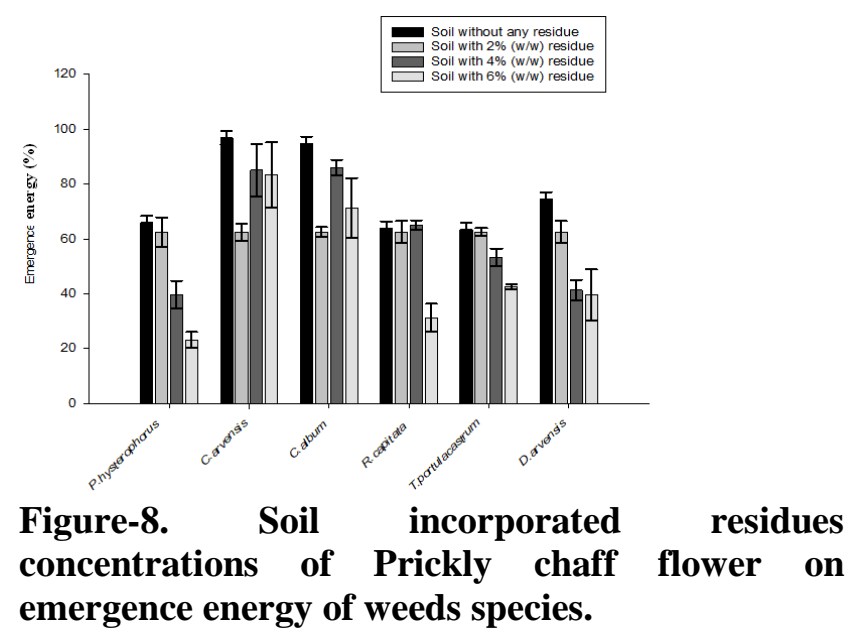

\section{Conclusion}

Our study outcomes clarified that prickly chaff flower exerted phyto-inhibitory influence on the germination of false amaranth, horse purslane, parthenium, goosefoot, field bindweed and jumby bean through its water extracts and soil-decomposition residues. Among weeds, false amaranth and field bindweed were proved to be most susceptible while parthenium weed to be the most resistant to phytotoxic effect of prickly chaff flower. Moreover, water extracts of prickly chaff flower were found to have more potent allelopathicity than its soil decomposed plant residues.

\section{Acknowledgement}

The authors of this manuscript would like to thank laboratory staff of Department of Agronomy, College of Agriculture, University of Sargodha, Sargodha, Pakistan for their support during the period of research.

Disclaimer: None.

Conflict of Interest: None. Source of Funding: None. 


\section{References}

Afridi RA and Khan MA, 2014. Reduced herbicide doses in combination with allelopathic plant extracts suppress weeds in wheat Pak. J. Bot. 46: 2077-2082.

Ahmad I, Ahmad MSA, Hameed M, Hussain M, Ashraf MY, Ahmad F and Malik H, 2012. Status of plant diversity in the Soone valley, Salt Range. Pakistan. Pak. J. Bot. 44: 59-62

Aldrich RJ and Kremer RJ, 1997. Weed-Crop Ecology: Principles in Weed Management. 2nd Ed. Iowa State Univ. Press. Ames, IA. 455 pp.

Bansal RP and Sen DN, 1981. Dispersal strategies in plants of the Indian Desert. J. Arid Environ. 4: 314.

Association of Official Seed Analysts (AOSA), 1990. Rules for testing seeds. J. Seed Technol. 12: 1112.

Daehler CC, Denslow JS, Ansari S and Kuo HC, 2004. A risk- assessment system for screening out invasive pest plants from Hawaii and other Pacific Islands. Conserv. Biol. 18: 360-368.

Dogra KS and Sood SK, 2012. Phytotoxicity of Parthenium hysterophorus L. residues towards growth of three native plant species (Acacia catechu wild, Achyranthes aspera L. and Cassia tora L.) in Himachal Pradesh, India. Int. J. Plant Physiol. Biochem. 4: 105-109.

Ellis RA and Roberts EH, 1981. The quantification of aging and survival in orthodox seeds. Seed Sci. Technol. 9: 373-409.

Farooq N, Abbas T, Tanveer A and Jabran K, 2020. Allelopathy for Weed Management. In: Mérillon JM., Ramawat K. (eds.) Co-Evolution of Secondary Metabolites. Reference Series in Phytochemistry. Springer, Cham. https://doi.org/10.1007/978-3-319-96397-6_16.

Fernandez-Perez M, 2007. Controlled release systems to prevent the agro-environmental pollution derived from pesticide use. J. Environ. Sci. Health Part B. 42: 857-862.

Hussain F and Gadoon MA, 1981. Allelopathic effect of Sorghum vulgare L. Pers. Oecologia (Berl) 51: 284-288.

Islam IU, Ahmed M, Asrar M and Siddiqui MF, 2014. Allelopathic effects of Chenopodium murale L. on four test speies. Fuuast J. Biol. 4: 39.

Huy LQ, 2004. Invasion of parthenium hysterophorus Linn. in chir pine forests and its effect on soil characteristics. Ph.D. dissertation, College of
Forestry Dr. Yashwant Singh Parmar University of Horticulture and Forestry Nauni, Solan.

Khaliq A, Matloob A, Farooq M, Mushtaq M and Khan M, 2011. Effect of crop residues applied isolated or in combination on the germination and seedling growth of horse purslane (Trianthema portulacastrum L.). Planta Daninha. 29: 121-128.

Khan N, Khan IU, Khan MA and Khan H, 2004. Major rabi and kharif weeds of agronomic crops of district Bannu. Pak. J. Weed Sci. Res. 10: 79-86.

Koesukwiwat U, Lehotay SJ, Mastovska K, Dorweiler KJ and Leepipatpiboon N, 2010. Extension of the QuEChERS Method for Pesticide Residues in Cereals to Flaxseeds, Peanuts, and Doughs. J. Agric. Food Chem. 58: 5950-5958.

Kruse M, Strandberg M and Strandberg B, 2000. Ecological effects of allelopathic plants-a review. NERI Technical Report. p. 315.

Leather GR and Einhelling FA, 1988. Bioassay of naturally occurring allelochemicals for toxicity. $\mathrm{J}$. Chem. Ecol. 14:1821-1828.

Macias FA, Molinillo JM, Varela RM and Galindo JC, 2007. Allelopathy-a natural alternative for weed control. Pest Manage. Sci.: formerly Pesticide Sci. 63: 327-348.

Marshall R, Hull R and Moss SR, 2010. Target site resistance to ALS inhibiting herbicides in Papaver rhoeas and Stellaria media biotypes from the UK. Weed Res. 50: 621-630.

MU XQ, HE HH and Dong ZG, 2008. Effects of water extract of two weeds on seed germination and seedling growth of different wheat varieties. Acta Bot. Boreali-Occidentalia Sin. 6: 017.

Qureshi R, Bhatti V and Saeed A, 2002. Obnoxious weeds - mankind's need. Hamdard Medicus. 45: 82-87.

Rajiv P, Rajeshwari S and Venckatesh R, 2013. BioFabrication of zinc oxide nanoparticles using leaf extract of Parthenium hysterophorus L. and its size dependent antifungal activity against plant fungal pathogens. Spectrochimica Acta Part A: Mol. Biomol. Spectroscopy. 112: 384-387.

Randhawa M, Cheema Z and Ali MA, 2002. Allelopathic effect of sorghum water extract on the germination and seedling growth of Trianthema portulacastrum L. Int. J. Agric. Biol. 4: 383-384.

Ros M, Goberna M, Moreno JL, Hemandez T, Garcia C, Insam H and Pascual JA, 2006. Molecular and physiological bacterial diversity 
of a semi-arid soil contaminated with different levels of formulated atrazine. App. Soil Ecol. 34: 93-102.

Ruan S, Xue Q and Tylkowska K, 2002. The influence of priming on germination of rice (Oryza sativa L.) seeds and seedling emergence and performance in flooded soils. Seed Sci. Technol. 30: 61-67.

Safdar ME, Tanveer A, Khaliq A and Naeem MS, 2014. Allelopathic action of parthenium and its rhizospheric soil on maize as influenced by growing conditions. Planta Daninha. 32: 243-253.

Safdar ME, Tanveer A, Khaliq A, Ali HH and Burgos NR, 2016. Exploring herbicidal potential of aqueous extracts of some herbaceous plants against parthenium weed. Planta Daninha. 34: 109-116.

SAS Institute, 2008. SAS/STAT 9.1 User's Guide the Regular Procedure, (Book Excerpt). SAS Institute, Cary, NC, USA.

Schooler SS, Cook T, Prichard G and Yeates AG, 2010. Disturbance-mediated competition--the interacting roles of inundation regime and mechanical and herbicidal control in determining native and invasive plant abundance. Biol. Invasions. 12: 3289-3298.

Shafique S, Javaid A, Bajwa R and Shafiqe S, 2007. Biological control of Achyranthes aspera and Xanthium strumarium in Pakistan. Pak. J. Bot. 39: 2607-2610.

Srivastav S, Singh P, Mishra G, Jha KK and Khosa RL, 2011. Achyranthes aspera - An important medicinal plant: A review. J. Nat. Prod. Plant Resour. 1: 1-14.

Steel RGD, Torrie JH and Dickey DA, 1997. Principles and procedures of Statistics. A Biometrical Approach $3^{\text {rd }}$ Edition. McGraw Hill Book Co., Inc., Singapore, pp: 172-177.

Systat Software Inc., 2008. SigmaPlot for Windows (development and testing procedures). Version
11.0. Triestram and Partner $\mathrm{GmbH}$, Bochum, Germany.

Tanveer A, Rehman A, Javaid MM, Abbas RN, Sibtain M, Ahmad AUH, Ibin-i-Zamir MS, Chaudhary KM and Aziz A, 2010. Allelopathic potential of Euphorbia helioscopia L. against wheat (Triticum aestivum L.), chickpea (Cicer arietinum L.) and lentil (Lens culinaris Medic.). Turk. J. Agric. For. 34: 75-81.

Tanveer A, Safdar ME, Tariq MA, Yasin M and Noorka IR, 2014. Allelopathic inhibition of germination and seedling vigor of some selected crops by Achyranthes aspera L. Herbologia. 14: 04.

Vora A, Patel J and Punjani B, 1989. Comparative photosynthesis and levels of metabolites in leaves and chloroplasts of sun-adapted and shadeadapted plants of Achyranthes aspera L. J. Environ. Biol. 10: 159-164.

Wakjira M, Berecha G and Tulu S, 2009. Allelopathic effects of an invasive alien weed Parthenium hysterophorus L. compost on lettuce germination and growth. Afr. J. Agric. Res. 4:1325-1330.

Weston LA and Duke SO, 2003. Weed and crop allelopathy. Crit. Rev. Plant Sci. 22(3-4): 367-389.

\section{Contribution of Authors}

Safdar ME: Supervised the experiment and approved the manuscript

Aslam A: Performed experiment

Qamar R: Statistical analysis and manuscript write up

Ali A: Provided experimental inputs

Javaid MM: Designed experimental layout and manuscript write up

Hayyat MS: Helped in chemical analysis

Raza A: Helped in chemical analysis 